\title{
Portrait of Diversity Kampung Islam Kepaon Through Web-Based Digital Media Visualization
}

\author{
$1^{\text {st }}$ Riza Wulandari ${ }^{1}, 2^{\text {st }}$ Nyoman Ayu Nila Dewi ${ }^{2}$ \\ Rizawulandari@stikom-bali.ac.id ${ }^{1}$, Nila@stikom-bali.ac.id ${ }^{2}$ \\ Departement of Information System, STIKOM Bali, Indonesia ${ }^{\mathbf{1 2}}$
}

\begin{abstract}
This research aims to introduce the variety of Kampung Islam Kepaon by utilizing the digital media visualization through website by using Hypertext Preprocessor programming language. Kampung Islam Kepaon is one of the village exists in Bali Island with its high plurality and social, culture and economic diversity which has a potential for identity strengthen and increasing the village autonomical economic. Thus researched is hoped to be able to give information contribution to general public especially for the domestic tourists and foreign tourists about the plurality that exists in Bali from the art, culture, tradition, and religion point of view, and also the condition of the people in Kampung Islam Kepaon. The hyperealist theory and simulacra theory by Jean Baudrillard are used in the analysis of this research. The method which is used to get the information about Kampung Islam Kepaon is qualitative research which focused on the visual aspect by gathering data using interview and documentation. The result of this research is the visualization display about the portrait of Kampung Islam Kepaon whivh is filled with the history, cultural product, economic potential and social condition of the society there which is transferred into digital media such as videos and photos which can be found in Kampung Islam Kepaon website.
\end{abstract}

Keywords: visualization of media digital, website, Kampung Islam Kepaon

\section{Introduction}

The development of today's technology is starting to provide easy offers for every user; one of it is digital media. Digital media is a technology product that provides new opportunities for information and entertainment seekers through contents which are wrapped in interesting ways. Based on interactive communication technology on computer networks, the use of the internet in digital media is displayed as a means of production and dissemination of information. Definition of digital media is a medium that is presented online on the internet which contains all types or formats of media that can only be accessed by using the internet which in it containing text, video and sound. Categories of such digital media are e-mail, websites, blogs, social media that can be used as online communication.

Kampung Islam Kepaon is a portrait of a village in Denpasar City area which still instills the values of the traditions of the surrounding population. This village is located in the southern part of Denpasar, which is the Pamogan Village. [1] The diversity of the religious population there is unique which can be seen that there are Muslims community who are surrounded by Hindu residents. The process of cultural acculturation is present in Pamogan Village on the portrait of the Kampung Islam Kepaon with mutual tolerance between residents 
of one population. The condition of the village town that lives in the midst of modernization is upside down with what exists today. The urban industrial sector is growing rapidly, requiring the villages in urban areas to have various ways to survive for their life. The more urban villages do not have distinctive characteristics, then they will gradually be eroded by the presence of elite housing manifested from the resolution of the slums and irregular urban villages.

There are some identities that reflect the Kampung Islam Kepaon, one of them is plurality. The people there live side by side although they are dominated by Hindus. This village has cultural production that can have an effect on improving the economy and strengthening the Muslim identity of the community there. Unfortunately, with the complexity of cultural production and the social conditions of people who walk side by side without conflict until now there has been no recording or visual recording of the Kepaon Islamic Village. From this, this research was conducted to introduce Kepaon Islamic Village by utilizing digital media in the form of websites. The website is a collection of pages that display information on text data, still or motion picture data, animation data, sound, video or a combination of all that is both static and dynamic which form a series of interrelated buildings where each is connected to hyperlink networks. It is said to be static if the website information content is fixed, it rarely changes and the information is submitted only from the website owner. While it is considered to be dynamic if the website information content is always changing and the information is two-way interactive information from the owner and user of the website. In this case, the creation of digital media in the form of a website for the introduction of Kepaon Islamic Village is static. [2]

\section{Literature Review}

Conceptual Definition

Kampung Islam Kepaon Trail Record

Discussing the history of the Kampung Islam Kepaon is closely related to the history of the entry of Islam in Bali. The first touch of Islam in Bali around the year of the collapse of the Majapahit kingdom, the first place and origin of Islamic community groups in Bali can be chronologically traced to the kings' (kingdom) government in Bali and the arrival of Dutch colonialism in Bali. The entry point of Islam in Bali varies, through business lines, marriages, political lines or on the basis of federation in war. Islam first came to Bali in the village of Gelgel, the kingdom of Klungkung during the reign of Dalem Waturenggong, around 1460 AD. It was marked with the arrival of the messenger from the Demak Sultanate. Sources that are used including Babad Dalem and Kidung Pemancangah, oral stories and some informants in the area of Muslim villages. After the Gelgel area, it was followed by the entry of Islam in several areas in Bali. In Jembrana it was brought by Syarif Abdullah bin Yahya Al-Qadry in 1800, and settled in the village of Loloan, now a Muslim village of Loloan. In Buleleng it was in Pegayaman and Bugis Singaraja villages, while in Badung it was on Serangan Island. About the emergence of the Kampung Islam Kepaon many sources wrote that the entry of Islam in Kepaon was through government or power. When Cokorda Pemecutan III was in power, a ship was stranded by the beach near Kuta area. They experienced damage to the boat, they were then cultivated by the rulers of Badung Cokorda Pemecutan III. These newcomers were led by Raden Sastroningrat, a noble of Madura. Another version is Raden Suryodiningrat, a Madurese nobleman who lives in Mataram (Yogyakarta).

By the King of Badung they were promised a freedom and would be married to their daughter if they were willing to help the king in the battle against the kingdom of Mengwi and defeat him. Raden Sastroningrat agreed to him, then together with the Badung troops 
supported by the Bugis army from the island of Serangan stormed the Mengwi kingdom. In the battle the Mengwi kingdom was defeated by the combined forces. The combined forces are described as very ferocious and violent. Bugis, Madurese and Javanese in Badung were mobilized and ordered to prepare for war, their leaders drank "war drugs", and their influence was felt, like someone possessed. For his services Raden Sastroningrat was married to the daughter of the king Cokorda Pemecutan III whose name was Anak Agung Ayu Rai as he promised. Raden Sastroningrat then brought Anak Agung Rai to Mataram (Yogyakarta), and then brought to Bangkalan Madura. After entering Islam Anak Agung Ayu Rai was given name Siti Khotijah, and her knighthood was Raden Ayu Mas Mirah. Upon returning from Java, the husband and wife immediately returned to the Badung kingdom and were well received. But after the king learned that his daughter had converted to Islam, he immediately ordered to exile the princess in Kebon (this place is also called Karang Semaya or Batan Nyuh), which is now known as Kepaon. The princess lives in Kepaon with her followers who were Muslim and have lived for generations until now. [3]

In another source it is revealed that when Islam was good enough Anak Agung Ayu Rai, by her husband Raden Sastroningrat was brought back to Bali. At one time, when it was time to perform Maghrib prayer, he was suspected of committing black magic (santet). By the royal guard he was reported to the king, then the king ordered him to kill her. So Anak Agung Ayu Rai was killed while praying and wearing rukuh (mukena), an Islamic white women's prayer dress. Because of wearing this all-white outfit, Anak Agung Ayu Rai wss thought to be doing a pengleakan (black magic) procession. Especially when praying to say "Allohu Akbar", in the ears of Balinese Hindus it is thought that they say "lakar mekeber" (the spirit has flown). Therefore, she was impaled to death. The tomb in the holy month of Ramadan is always visited by Madurese and Javanese living in Bali, besides the Balinese Alone. Even now it is part of the visit for participants of "pilgrimage tours" from all over Indonesia. Raden Sastroningrat died and was buried in Ubung. As long as the husband and wife of Raden Sastroningrat and Anak Agung Ayu Rai lived in Ubung and Kepaon, many of Raden Sastroningrat's relatives arrived or stayed in the land. So the descendants of the Raden Sastroningrat and Anak Agung Ayu Rai descendants, together with their followers and relatives, are the forerunners of the Islamic community or community in Kepaon Village. But many of their offspring spread to other places, it was due to marriage and work, so that together with other Muslims who came later formed new communities in various locations in the Badung area.

Kepaon's Islamic community relations with Puri Pemecutan (Badung kingdom) remain well-established, even at every kingdom ceremony the Kampung Islam Kepaon gets an invitation and a special place for them. Whereas in every Islamic holiday ceremony at Kepaon is always attended by the Pemecutan Castle even though their religion is different, which are Hinduism and Islam. The followers of couple Raden Sastroningrat and Anak Agung Ayu Rai were also given royal estate and the land has now become part of the Kampung Islam Kepaon. Etymologically the name Kepaon comes from the word paon (Balinese), pawon (Javanese) which means kitchen. While in Toponymy which is about the origin of naming a place. As the function of toponymy of a region is a means to explore and reveal the history and culture of a region or region contained by toponymies. Toponymies can be used as one source of history. In Toponymy, it is called Kepaon because the people in Kepaon village build paon (kitchen) on the outskirts of the village, so the whole village is surrounded by a kitchen. Every person who wants to go to this village always calls going "ke Paon" (to paon), eventually becoming Ke-paon until now. Administratively it is located in Pemogan Village, South Denpasar District, Denpasar City. Until now the Islamic village of Kepaon continues to grow both 
physically and in population. Although it has experienced rapid development, the Muslim community of Kepaon keeps the values of Balinese tradition and culture inherent in them, because they feel they have become Balinese. Kampung Islam Kepaon continues to live side by side with Balinese who are mostly Hindus.

Digital Media

Digital media is a media whose content is a combination of data, text, sound, and various types of images stored in digital format and disseminated through networks based on broadband optical cable, satellite and microwave systems [4] Media is currently developing and will surely continue to grow which follows the changing times. The development of these media can be said in terms of technology, communication, and information such as the internet, computers, mobile phones and sites. Most of the media is currently dominated by digital technology products that have the characteristics of being manipulated, networked, solid and easy, and also interactive.[5]

Website

A website or site can be defined as a collection of pages that display information on text data, still or moving image data, animated data on sounds, videos and / or a combination of all of them. Both static and dynamic are forming a series of interrelated buildings where each is connected to a network of pages. [6] The development of the internet today has supported the use of computers in all fields. The internet can also be accessed by whomever, whereever and whenever needed by its users. At present the website also becomes a digital communication innovation that makes it easy for the general public to reach both narrow and wide scales. The website is useful in various types depending on the purpose and type of website that is built. Broadly speaking, the benefits of the website are as promotional media, marketing media, information media, educational media and communication media

State of The Art

Research was conducted by Riza Wulandari (2017) on the actualization of the Kampung Islam Kepaon community. From this it can be concluded that the actualization of the Islamic community in Denpasar through several activities that are routinely carried out, namely running the tradition of rodat dance, megibung tradition carried out during the month of Ramadan, the application of Balinese language in daily communication, Islamic-based education in the Kampung Islam Kepaon.

Research conducted by Nuryahman (2015) on the people of Kampung Islam Kepaon shows that there is acculturation occurred from the Islamic community with the Balinese Hindu community. There is an identity as a result of cultural acculturation that is manifested in daily life that is full of tolerance.

\section{Methode}

This research is a single case study research, which is a research procedure that focuses on one characteristic. In this case, it is reviewed in terms of one target or location. Case studies are included in qualitative research. In qualitative research can be interpreted as one of the main approaches which is basically a general name only from a large family of research methodologies (Bungin, 2003: 19) Case studies explore the problems of explanatory questions and the use of strategies from case study (Yin, 2005: 9) This research was conducted in Kampung Islam Kepaon, Pemogan Village, Denpasar. Primary data sources obtained directly 
from informants, literature studies, author documents and existing visual data. Processing data collection using interviews, observation and documentation. The process of selecting informants is classified based on social status and organizational management. The validity of the data was obtained from officials from agencies and communities outside the Kampung Islam Kepaon,. Data processing uses interactive models by reducing data, presenting data and drawing conclusions.

In this visualization research, the system is also made using the PHP programming language. PHP has the extension Hypertext Prepocessor which is a programming language which is used to build dynamic websites. This PHP is open source so that it can be used for free and is able to cross platforms.

From data collection obtained from interviews and field observations, are then structured and visualized by utilizing digital media in the form of websites.

\section{Result and Dicussion}

Diversity in Indonesia is actually able to create peace based on pluralism and the spirit of Bhinneka Tunggal Ika. Bali Island with ethnic, culture and tradition diversity which consists of various types of social conditions can create harmony in each element of culture. It is undeniable, that the island of Bali has also been contaminated by cultural acculturation from foreign parties, namely foreign tourists. However, the cultivation of local wisdom continues to be carried out by the local government and the surrounding community in order to be able to walk in a balanced manner as practiced by the people of Kampung Islam Kepaon.

Kampung Islam Kepaon is one of the villages located in the southern city of Denpasar. This village is inhabited by \pm 500 residents with the majority religious identity of Islam. This village is the only village in the center of Denpasar. Outside the territory of the Islamic Village, Kepaon is inhabited by Hindus who have long lived in the region. Referring to the diversity based on Bhinneka Tunggal Ika, Kampung Islam Kepaon is very instilling the value of diversity in the processes of everyday life. It can be seen from the social conditions of the local community, the diversity of traditions that include other religions without any limitations, organic and mechanical solidarity created in the younger generation. Apart from social and cultural aspects, as well as social solidarity that was built in the Kampung Islam Kepaon. On the economic side, there is also a process of building identity to maintain the existence of Kampung Islam Kepaon in the midst of fluctuating erratic urban conditions and industrialization which is increasingly developing in this Digital era without ignoring ethnic diversity.

Cultural, traditional, religious, economic and social complexities in the Kampung Islam Kepaon have received attention for foreign and domestic tourists and the mass media. From various events held by the people of Kampung Islam Kepaon, mass media from local and national are always present to enliven the event. One of the events of Kampung Islam Kepaon which was attended by many people, mass media or tourists is the tradition of megibung. Besides the tradition of megibung, there are many more traditions and activities that can be used as a strengthening of Islamic identity and diversity that still exists on this Island of the Gods.

The attitude of self-actualization possessed by the people of Kampung Islam Kepaon must be positively appreciated by the community, government, academia environment as a form to introduce plurality diversity on the island of Bali as seen in the Kepaon Islamic Village. One 
means that can be used as a medium of information, communication and actualization in the era of digitalization is to build a website system that contains all the components in the Islamic Village of Kepaon such as history, cultural production owned by the village community, any economic potential which can strengthen social identity and solidarity between tribes, religions and ethnicities, religious tourism trips about Islam in Bali, especially this village and also a space for information related to population in Kampung Islam Kepaon.

This website is built using the PHP programming language which can be seen effectively by the general public. The introduction process of Kepaon Islamic Village by utilizing digital media as visualization is expected to provide an overview for digital media connoisseurs who will visit Bali for religious tourism purposes. This website is also expected to provide knowledge and information to the general public that exist in the island of Bali which is dominated by the Hindu community. There are also activities and social life carried out by Muslims that they co-exist with each other. The Display of the website of Kepaon Islamic Village.

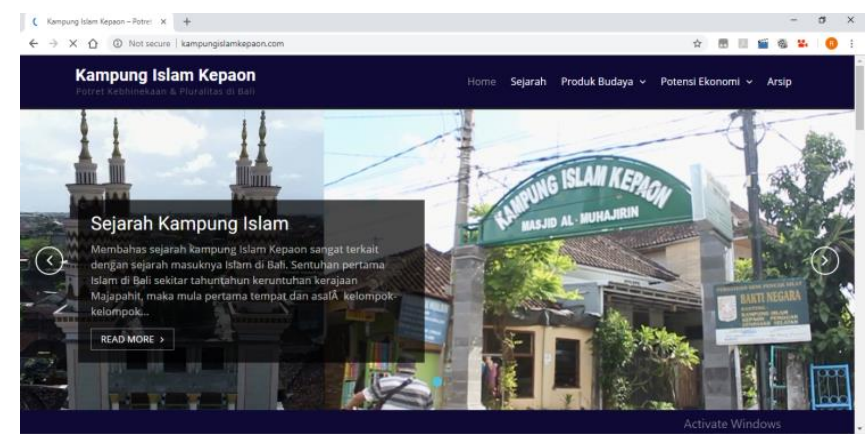

Image 1. The front page display of Kampung Islam Kepaon Denpasar Website

On the display above, it contains a website address that can be accessed to find information about Kampung Islam Kepaon. This can be accessed by typing www.kampungislamkepaon.com in the browser owned by the user. After entering the website address, the display will appear as can be seen in the picture above. In the above view, users can choose what features will be searched or seen such as the history of Kampung Islam Kepaon, what cultural production is there, economic potential and others. Not only this, there is also an event feature that is usually held by the people of the Kampung Islam Kepaon community and video footage of the results of research conducted by the STMIK STIKOM Bali student team.

Fitur sejarah yang terdapat pada website Kampung Islam Kepaon, berisi tentang proses historical jejak rekam terbentuknya kampung tersebut.

The historical features contained in the Kampung Islam Kepaon website, contain the historical process of the trail record of the formation of the village 


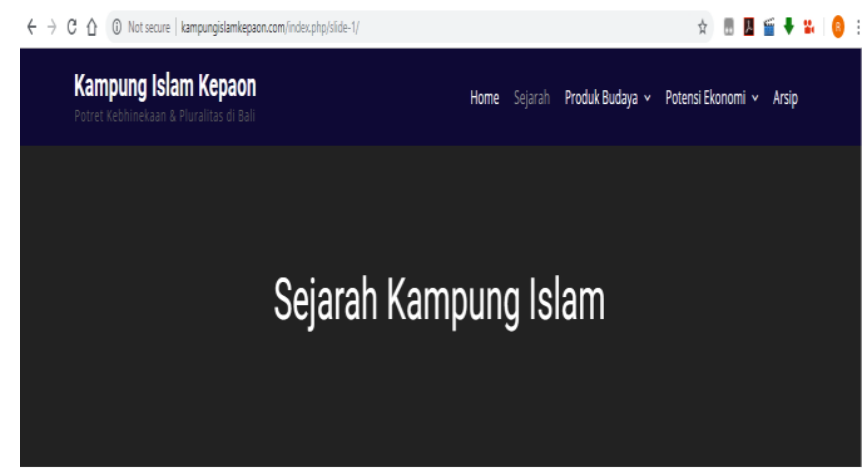

Image 2 Kampung Islam History Feature

Setelah menelusuri konten fitur sejarah dari Kampung Islam Kepaon, ada beberapa konten lain yang bisa kita peroleh informasi tentang kampung ini adalah seperti pada gambar dibawah ini.

After browsing the historical feature content of the Kepaon Islamic Village, there are several other content that can be found some nformation about this village as shown below.

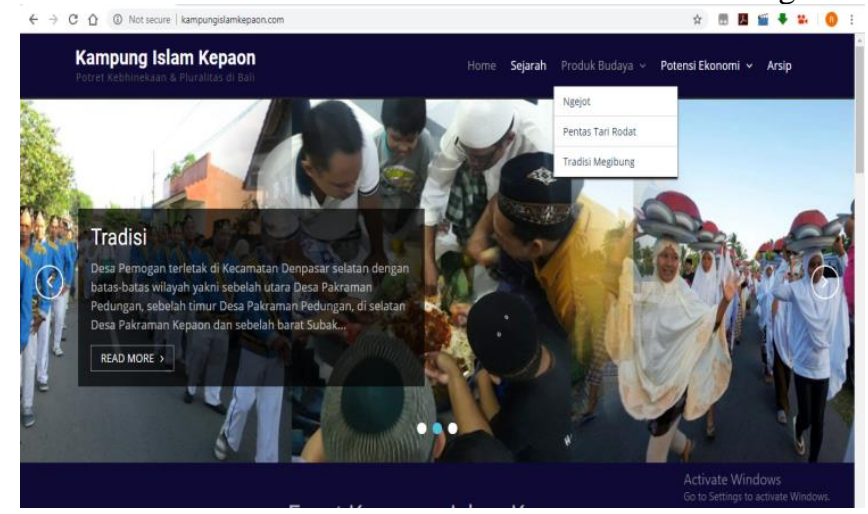

Image 3 The Culture Product of Kampung Islam Kepaon

In the cultural production column the user can see what traditions are in kampung Islam Kepaon such as ngejot tradition, megibung tradition and rodat dance tradition. 

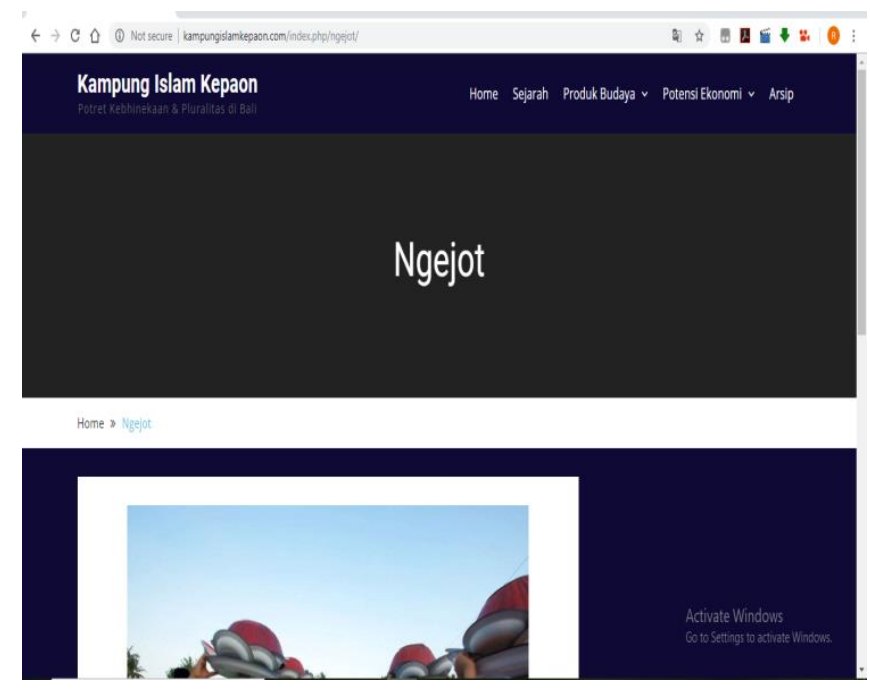

Image 4 Ngejot Tradition

In the ngejot tradition above, it tells about the giving food for the religious people in Kampung Islam Kepaon as a symbol of the celebration of Islamic Holidays and also vice versa. Hindus are the ones who practice this tradition, when giving food to Muslims. They usually serve chickens and light snacks.

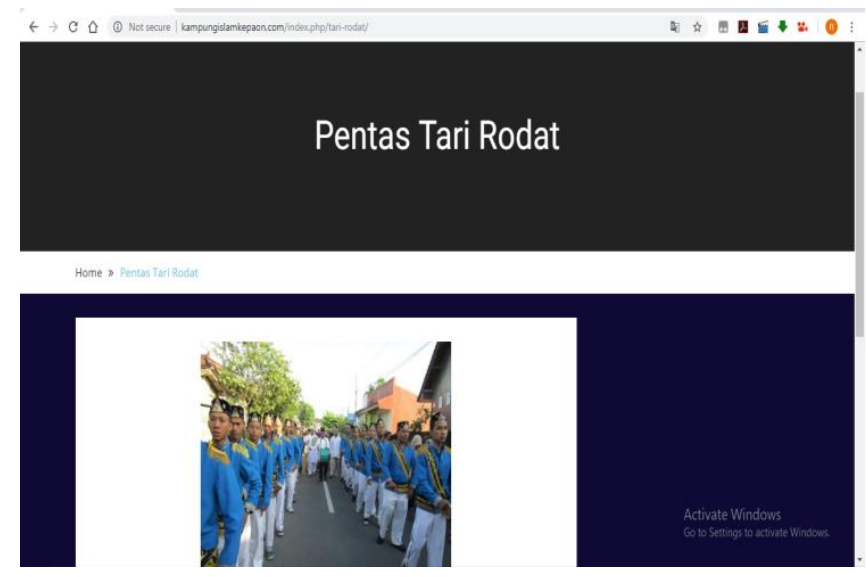

Image 5 Rodat Dance Performance

In addition to the ngejot tradition, there is also a Rodat dance performance performed during Hindu celebrations or it could also be at the birthday of the Prophet Muhammad. 

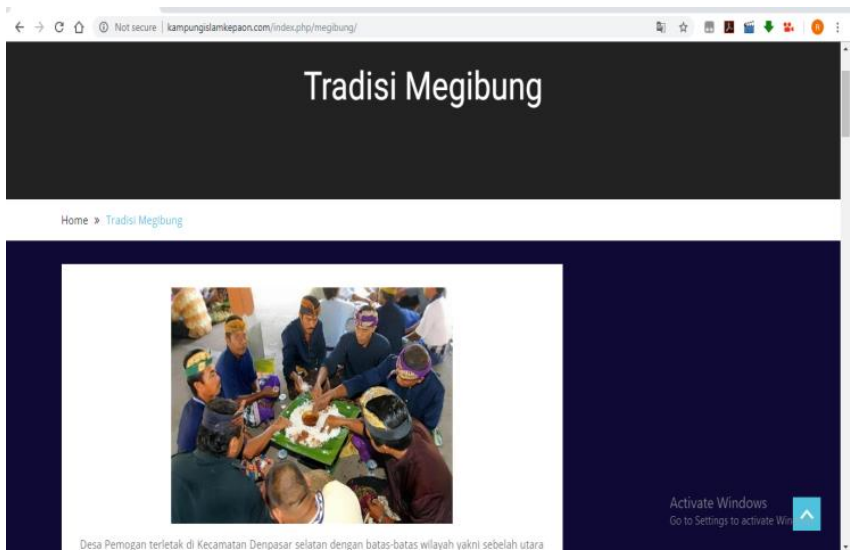

Image 6 Megibung Tradition

The megibung tradition above, is one of the traditions that are most visited by the general public and even foreign and local tourists. This tradition is an amalgamation of the megibung tradition owned by Balinese Aga people from Karangasem which has meaning as togetherness. The deconstruction that was processed by the people of the Kampung Islam Kepaon only changed in the presentation of food and the pronunciation of prayer according to the Islamic religion. The pattern contained in this tradition is still the same, which is done by 6-8 people by eating food from 1 tray containing rice, side dishes of vegetables. This activity is carried out on 10 days, 20 days and 30 days of Ramadan. The electronic media, many print media are visiting to cover the megibung tradition activities which are always carried out continuously and for generations.

After visiting cultural product content, users can also see the economic potential content in Kampung Islam Kepaon.

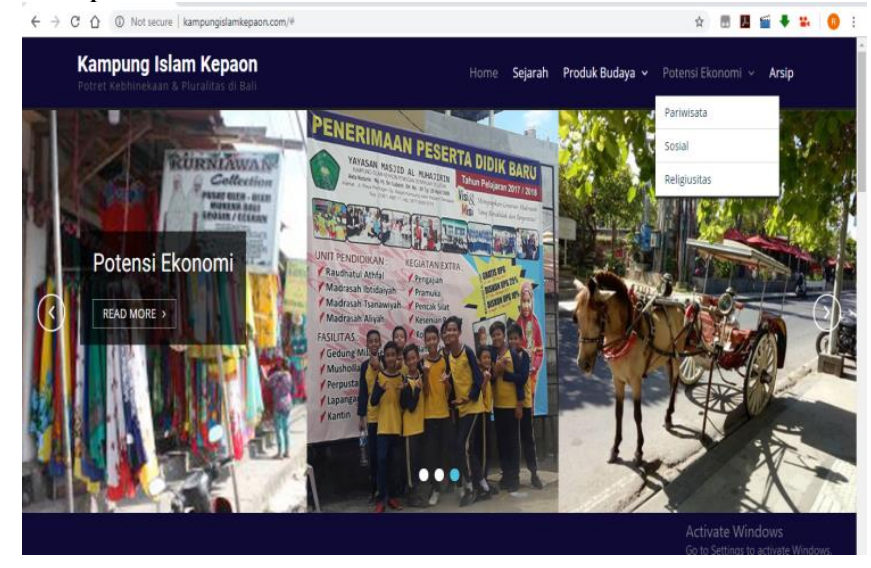

Image 7 Economic Potential

The economy is one of the categories in the development of a region. In Kampung Islam Kepaon, there are several economic categories that can be used as potential in building regional autonomy and improving competitiveness such as aspects of tourism, social and also 
religious aspect. Of the three categories, the economic potential that exists in the tourism aspect is able to create an increase in the village economy amid industrialization. This economic potential is seen in the UKM Mukena Bali and Kampung Dokar in Kampung Islam Kepaon.

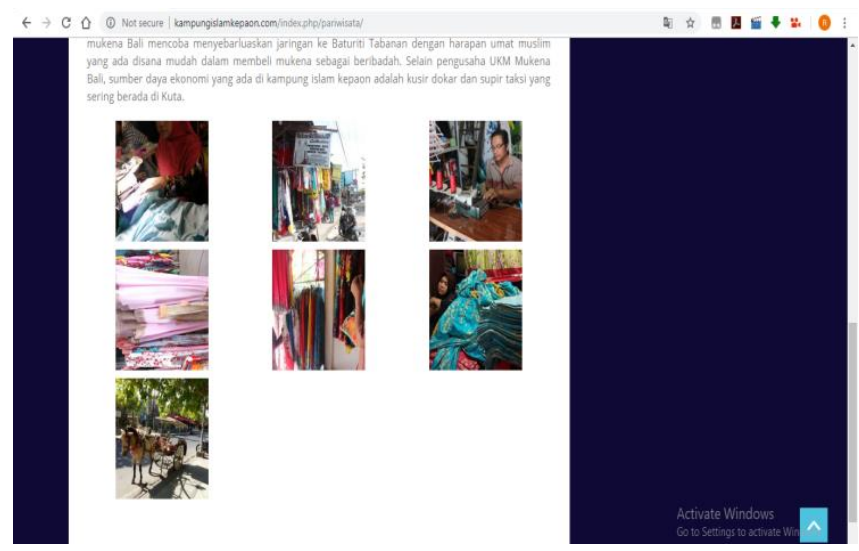

Image 8 Economic Potential of Tourism Aspect

The Mukena Bali UKM is very well known in the eyes of foreign tourists and domestic tourists. The tourists usually buy typical Balinese Mukena in the center of Balinese souvenirs. The center of the UKM Mukena Bali actually comes from the Pemogan Village area, one of which is Kampung Islam Kepaon. With prices that are cheaper than those in the Bali Souvenir Center, tourists can get more affordable retail and wholesale prices.

The existence of the charioteer has begun to fade in the middle of the industrial revolution which presents the ease, efficiency and speed of driving. But this did not make the charioteer goes backwards. They continue to exist in tourism places such as Kuta Beach, Legian, Seminyak, and others. In the Kampung Islam Kepaon there is a collection of dokar drivers called kampong dokar. They continue to try to maintain existence in the midst of modernization.

On the website that provides information about this Kampung Islam Kepaon, there are also videos that can be seen with a more interesting and interactive package from a summary of the socio-cultural conditions, the life of the surrounding community, history, and other matters relating to Kampung Islam Kepaon. 


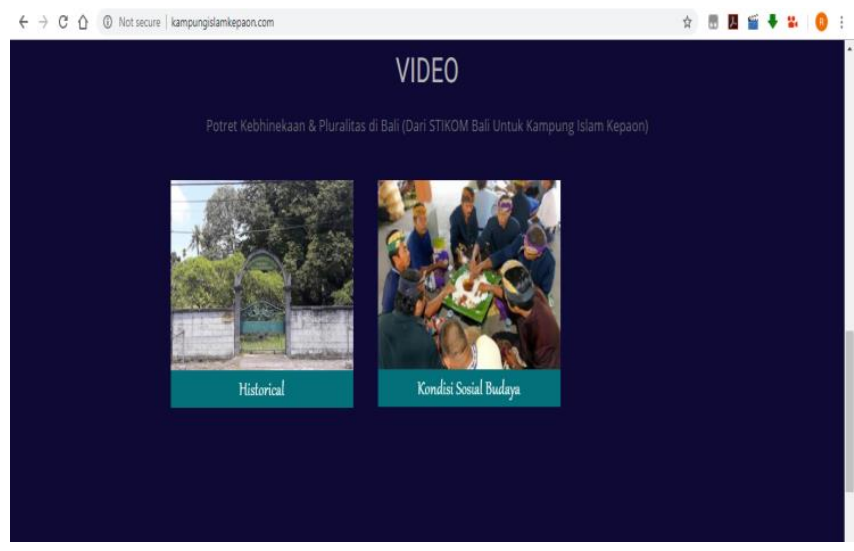

Image 9 Kampung Islam Kepaon Video

In addition to video, when users or visitors want to visit this village but not knowing the location of the place, location content has been provided that is directly detected from Google Map so that users are easier to do religious tourism travel.

The visitors can also do religious tourism while visiting Bali, starting from Kusamba Gelgel area where there is a wali's tomb as the spreader of Islam, and then visiting the Tomb of the founder of Kepaon Islamic Village namely Raden A. Siti Khodijah located in the Monang-maning area of Denpasar. This tomb is often visited by grave pilgrims domestically and internationally. From the appearance of the website that has been built to provide benefits as the dissemination of information and communication, it is expected to continue to run and be managed both by users from Kampung Islam Kepaon so that the general public can continue to get information about the event, developments from the village.

\section{Conclution}

Kampung Islam Kepaon is one of the manifestations of the existence of the urban village which currently still implements plurality and high diversity. Caring for diversity in a place with the complexity of cultural diversity, customs, and traditions is not easy. The cultivation of local wisdom from generation to generation continues to be done so that the existence of the Islamic Village of Kepaon, amid the domination of Hindus, is maintained. Seeing the condition of Indonesian society in a crisis of tolerance, one effort to keep the portrait of diversity in Bali intact is to maintain a website content as a form of positive communication and information media that can be accessed by the general public, foreign and domestic tourists. This website about Kampung Islam Kepaon contains records, cultural products, economic potential, and videos containing all the activities of Kepaon Islamic Village. With this website, it is expected to strengthen the identity of the Kepaon Islamic Village as a strong village of plurality and can be used as a religious attraction for tourists. 


\section{References}

[1] Ardika and I. Wayan, No TitlePustaka Budaya dan Pariwisata. Pustaka Larasan, 2007.

[2] [2] Hidayat and Rahmat, No TitleCara Praktis Membangun Website Gratis: PengertianWebsite. Jakarta: PT Elex Media Komputindo Kompas, Granedia, 2010.

[3] [3] Saidi, Shaleh, and Y. Anshori, No TitleSejarah Keberadan Umat Islam di Bali. Majelis Ulama Indonesia (MUI), 2002.

[4] T. [4] Flew, No TitleNew Media: an introduction. New York: Oxford University Pers, 2008.

[5] [5] Ardianto and [5] Ardianto, Komunikasi Massa Suatu Pengantar. Bandung. Simbosa Rekatama Media, 2007.

[6] [6] Garett, Renee, and S. D. Jason Chiu, Lh Zhang, "Young. A Literature Review : Website Design and User Engangement. Online Journal of Communication and Media Technologies," vol. 06, no. 3July, 2016. 